\title{
Acceleration of the direct identification of Staphylococcus aureus versus coagulase-negative staphylococci from blood culture material: a comparison of six bacterial DNA extraction methods
}

\author{
A. J. M. Loonen • A. R. Jansz • H. Kreeftenberg • \\ C. A. Bruggeman - P. F. G. Wolffs • \\ A. J. C. van den Brule
}

Received: 23 June 2010 / Accepted: 1 October 2010 / Published online: 24 October 2010

(C) The Author(s) 2010. This article is published with open access at Springerlink.com

\begin{abstract}
To accelerate differentiation between Staphylococcus aureus and coagulase-negative staphylococci (CNS), this study aimed to compare six different DNA extraction methods from two commonly used blood culture materials, i.e. BACTEC and BacT/ALERT. Furthermore, we analysed the effect of reduced blood culture incubation for the detection of staphylococci directly from blood culture material. A real-time polymerase chain reaction (PCR) duplex assay was used to compare the six different DNA isolation protocols on two different blood culture
\end{abstract}

A. J. M. Loonen · A. R. Jansz · A. J. C. van den Brule PAMM Laboratory for Medical Microbiology,

Eindhoven/Veldhoven, The Netherlands

\begin{abstract}
A. J. M. Loonen - A. J. C. van den Brule Centre for Medical Molecular Diagnostics, Fontys University of Applied Science,

Eindhoven, The Netherlands
\end{abstract}

\author{
A. J. M. Loonen - C. A. Bruggeman · P. F. G. Wolffs \\ Department of Medical Microbiology, \\ Maastricht University Medical Centre, \\ Maastricht, The Netherlands \\ H. Kreeftenberg \\ Department of Intensive Care, Catharina Hospital, \\ Eindhoven, The Netherlands
}

\footnotetext{
A. J. C. van den Brule ( $\bowtie)$

Department of Molecular Diagnostics, Catharina Hospital/PAMM Laboratory, Michelangelolaan 2,

5623 EJ Eindhoven, The Netherlands

e-mail: a.van.den.brule@pamm.nl
}

systems. Negative blood culture material was spiked with methicillin-resistant S. aureus (MRSA). Bacterial DNA was isolated with automated extractor easyMAG (three protocols), automated extractor MagNA Pure LC (LC Microbiology Kit $\mathrm{M}^{\text {Grade }}$ ), a manual kit MolYsis Plus and a combination of MolYsis Plus and the easyMAG. The most optimal isolation method was used to evaluate reduced bacterial incubation times. Bacterial DNA isolation with the MolYsis Plus kit in combination with the specific B protocol on the easyMAG resulted in the most sensitive detection of $S$. aureus, with a detection limit of $10 \mathrm{CFU} / \mathrm{ml}$, in BacT/ALERT material, whereas using BACTEC resulted in a detection limit of $100 \mathrm{CFU} / \mathrm{ml}$. An initial $S$. aureus or CNS load of $1 \mathrm{CFU} / \mathrm{ml}$ blood can be detected after $5 \mathrm{~h}$ of incubation in BacT/ALERT 3D by combining the sensitive isolation method and the tuf LightCycler assay.

\section{Introduction}

Staphylococcus aureus is a pathogen which can cause both hospital- and community-associated infectious diseases, ranging from minor skin infections to endocarditis, bacteraemia, sepsis and septic shock [1]. Sepsis can result in high morbidity and mortality. In the United States, bloodstream infections develop in approximately 250,000 people annually [2]. In the Netherlands, the incidence of patients admitted to the intensive care unit (ICU) with severe sepsis is in the range of around 8,643 \pm 929 per year [3]. Currently, blood culture is the gold standard for the identification of pathogens from suspected bacterial sepsis patients. Unfor- 
tunately, blood culture is time-consuming, taking at least 24-72 $\mathrm{h}$ for the final determination of the bacteria causing the disease. Staphylococci are the most common Grampositive organisms in blood cultures. Differentiating $S$. aureus from coagulase-negative staphylococci (CNS) is important, because sepsis with $S$. aureus is common and virulent, with mortality rates in the range of $20-30 \%$ [4]. CNS are often considered as being contaminants in blood cultures due to the fact that these species are members of the normal skin flora and mucous membranes, and can contaminate the sample when it is taken. However, it is known that CNS infections are increasingly recognised as clinically relevant infections and confirmation on the presence of these species in blood culture is, therefore, important (reviewed in [5-8]). Several molecular methods for the rapid and accurate detection of bacteria from positive blood culture material have been described, including (commercial) real-time polymerase chain reaction (PCR)-based diagnostic tests [9-11], fluorescence in situ hybridisation [12, 13], matrix-assisted laser desorption ionisation time-of-flight mass spectrometry (MALDI-TOFMS) [14] and also DNA micro-arrays [15, 16]. However, all of these techniques are used on positive blood culture material.

Reduction in the time to obtaining results can be achieved by applying molecular methods either directly on whole blood or on blood culture material with reduced incubation times. Ideally, usage of whole blood is preferred but the techniques that are now available are often not sensitive enough, clinically, as has been shown by others investigating a commercial real-time PCR test currently available [17-19]. Blood culture materials are known to contain inhibiting factors which can reduce detection in a sensitive real-time PCR [20-23]. It is, therefore, important to include a good isolation method in the molecular diagnostic strategy, which is able to efficiently remove inhibiting factors and one which still allows sensitive DNA detection by PCR.

In this study we compared six different, both manual and automated, bacterial DNA isolation methods for two commonly used blood culture systems, i.e. BACTEC (Becton Dickinson) and BacT/ALERT (bioMérieux), to be able to find the most sensitive bacterial DNA isolation method. Additionally, we investigated the occurrence of inhibition in PCR amplification after DNA isolation. A sensitive real-time PCR assay was designed to be able to detect staphylococci and to differentiate $S$. aureus from CNS (Loonen et al., manuscript submitted). Subsequently, this real-time PCR was used in combination with the optimal DNA isolation method to investigate the level of time reduction to identify staphylococci from blood culture material. The results were compared with conventional blood culture techniques used in diagnostic laboratories.

\section{Materials and methods}

Culture methods

Negatively cultured blood culture bottles, derived from routine diagnostics of both BACTEC (Becton Dickinson, The Netherlands) and BacT/ALERT (bioMérieux, The Netherlands) systems, were used in this study for spiking experiments (bottles have been cultured for 1 week and remained negative). Additionally, healthy volunteers donated $10 \mathrm{ml}$ blood as the input for the BacT/ALERT bottles. The bottles were incubated and handled according to the manufacturer's protocol.

\section{DNA isolation methods}

Methicillin-resistant S. aureus (MRSA) ATCC 33592 was cultured overnight on blood agar. Fresh plates were used to make a $2-\mathrm{McF}$ solution which was subsequently serially diluted $(1: 10)$ in negative blood culture material from both systems (BACTEC and BacT/ALERT). One hundred $\mu \mathrm{l}$ was plated on blood agar plates to check the number of CFU per sample. Three different isolation protocols on the NucliSens easyMAG (bioMérieux) were tested (generic, specific A and specific B protocol: the main difference between the protocols is the number of washing steps, with the least steps in the generic protocol and the most washing steps in the specific B protocol), one isolation kit (LC Microbiology Kit $\mathrm{M}^{\text {Grade }}$ ) on the MagNA Pure LC (Roche Diagnostics), the MolYsis Plus kit (Molzym $\mathrm{GmbH}$, Bremen, Germany) was used according to Molzym's instructions and in combination with the easyMAG. When MolYsis Plus was used in combination with the easyMAG, the manufacturer's instructions (Molzym) were followed until the BugLysis step and, subsequently, bacterial DNA was extracted according to the specific B protocol on the easyMAG. The input volume in each isolation was $200 \mu \mathrm{l}$, except for the MagNA Pure LC, where $100 \mu 1$ was used, and samples were always eluted in $100 \mu l$ elution buffer provided with each isolation method. Each extraction was performed at least 2-3 times in independent experiments. Phocine herpes virus type 1 (PhHV-1) was added to each sample eluate as an amplification and inhibition control. Samples were analysed with the LightCycler assay described below.

\section{LightCycler assay}

A duplex real-time PCR, detecting the tuf gene of both staphylococci and $S$. aureus specifically, is used as described in detail elsewhere (Loonen et al., submitted). In brief, the positions of the primers and probes were derived from the $S$. aureus tuf gene sequence (GenBank 
accession no. AF298796). The sequences of the primers and probes were as follows: Staphylococcus spp. forward primer ccaatgccacaaactcgtga (position 32-51), Staphylococcus spp. reverse primer cacgaccagtgattgagaatacg (position 371-349), S. aureus forward primer tcctggttcaattacaccaca tactg (position 583-608), S. aureus reverse primer ggaaata gaattgtggacgatagtttga (position 698-671), Staphylococcus spp. probe VIC-ccattcatgatgccagttg-BHQ1 (position 326344), S. aureus probe FAM-tgataatacgtatacttctgc-BHQ1 (position 637-617). Oligonucleotide primers were obtained from Eurogentec (Liège, Belgium), Staphylococcus XS probe and the $S$. aureus XS probe were obtained from Biolegio (Nijmegen, The Netherlands). PhHV-1 primers and VIC-labelled probe [24] were obtained from Applied Biosystems (Nieuwerkerk aan den IJssel, The Netherlands). PCR mixtures consisted of $5 \times$ LightCycler TaqMan Master mixture (Roche Diagnostics), $0.9 \mu \mathrm{M}$ concentration of each primer, $0.2 \mu \mathrm{M}$ concentration of each probe and Aquadest in a volume of $15 \mu l$ to which $5 \mu$ DNA sample was added, leading to a final reaction volume of $20 \mu \mathrm{l}$ in each capillary. Primers and probe targeting PhHV had a concentration of $0.1 \mu \mathrm{M}$ each and were used in a separate single real-time PCR assays. All samples were amplified on the LightCycler v2.0 (Roche Diagnostics) according to the following cycling parameters: an initial incubation step for $10 \mathrm{~min}$ at $95^{\circ} \mathrm{C}$ for enzyme activation and DNA denaturation, then, 45 cycles of $15 \mathrm{~s}$ at $95^{\circ} \mathrm{C}$ followed by $1 \mathrm{~min}$ at $60^{\circ} \mathrm{C}$. The results were analysed with LightCycler Software version 4.05 (Roche Diagnostics).

\section{Results}

Evaluation of different bacterial DNA extraction methods

In Table 1, the results are presented of the comparison of six different bacterial DNA extraction methods on S. aureus spiked blood culture material. The MagNA Pure LC (Roche Diagnostics) resulted in a detection limit of $10^{4} \mathrm{CFU} / \mathrm{ml}$ for both culture systems. On the easyMAG, three protocols were evaluated to isolate bacterial DNA from spiked clinical material, generic, specific A and specific B. We tested all three protocols and usage of the specific B protocol resulted in the best detection limit of $10^{2} \mathrm{CFU} / \mathrm{ml}$ of $S$. aureus in BacT/ALERT material. Although MolYsis Plus did not result in a low detection limit, we tested this manual kit in combination with the specific B protocol on the easyMAG. By combining both methods, all human DNA was removed and bacteria were lysed by the MolYsis Plus kit, and, subsequently, the easyMAG was used for the optimal washing and elution of bacterial DNA. It was possible to reduce the hands-on time and avoid possible contamination due to skipping of manual handlings. This combination of methods resulted in the most sensitive detection limit, i.e. $10 \mathrm{CFU} / \mathrm{ml}$, in BacT/ALERT material. The time to obtaining results for this combined method followed by real-time PCR is approximately $4-5 \mathrm{~h}$, but it strongly depends on the number of samples. No inhibition was observed in the real-time PCR, and all samples and controls showed similar $\mathrm{Cp}$ values in one run $(\mathrm{Cp} \pm 0.5)$. All experiments were performed at least 2-3 times.

\section{Reduced blood culture times}

To investigate the effect of reduced blood culture incubation for pathogen detection by PCR, a combination between the sensitive tuf LightCycler assay and the sensitive isolation method, the MolYsis Plus Kit in combination with the specific B protocol on the easyMAG, was analysed on S. aureus (ATCC 33592)-spiked BacT/ALERT blood culture bottles containing fresh blood from healthy volunteers. First, it was investigated how many CFU of $S$. aureus per $\mathrm{ml}$ needed to be present to be able to detect a signal with the LightCycler assay, therefore, 1,000, 100 and $10 \mathrm{CFU}$ were spiked in different bottles, both standard aerobic (SA) and standard anaerobic (SN) BacT/ALERT bottles. BACTEC bottles were not investigated due to the poorer results obtained with all of the isolation methods analysed. The results of this experiment are depicted in Fig. 1 and indicate that 1,000 CFU of $S$. aureus $(100 \mathrm{CFU} / \mathrm{ml}$ blood) could be detected by PCR immediately after spiking, indicating that no incubation step was required. The bottles
Table 1 Evaluation of six different DNA isolation protocols on blood culture material spiked with ten-fold dilution series of Staphylococcus aureus

\footnotetext{
*BACTEC; + BacT/ALERT; - not detected
}

\begin{tabular}{lcccccc}
\hline DNA isolation protocol & \multicolumn{7}{l}{ Detection limit in CFU/ml } \\
\cline { 2 - 6 } & $10^{5}$ & $10^{4}$ & $10^{3}$ & $10^{2}$ & 10 & 1 \\
\hline easyMAG generic & $+^{*}$ & $+^{*}$ & + & - & - & - \\
easyMAG specific A & $+^{*}$ & $+^{*}$ & $+*$ & - & - & - \\
easyMAG specific B & $+^{*}$ & $+^{*}$ & $+*$ & + & - & - \\
MagNA Pure LC & $+^{*}$ & $+^{*}$ & - & - & - & - \\
MolYsis Plus & $+^{*}$ & $+^{*}$ & - & - & - & - \\
MolYsis Plus + easyMAG specific B & $+^{*}$ & $+^{*}$ & $+^{*}$ & $+*$ & + & - \\
\hline
\end{tabular}


A

\begin{tabular}{ccccccc}
\hline & \multicolumn{6}{c}{ Timepoints (hours) } \\
\cline { 2 - 7 } Bacterial load CFU/bottle & 0 & 1 & 2 & 3 & 4 & 5 \\
\hline 1000 & $1 / 1$ & $1 / 1$ & $1 / 1$ & $1 / 1$ & $1 / 1$ & $1 / 1$ \\
100 & $0 / 1$ & $1 / 1$ & $1 / 1$ & $1 / 1$ & $1 / 1$ & $1 / 1$ \\
10 & $0 / 8$ & $0 / 8$ & $0 / 8$ & $2 / 8$ & $5 / 8$ & $8 / 8$ \\
\hline
\end{tabular}

B

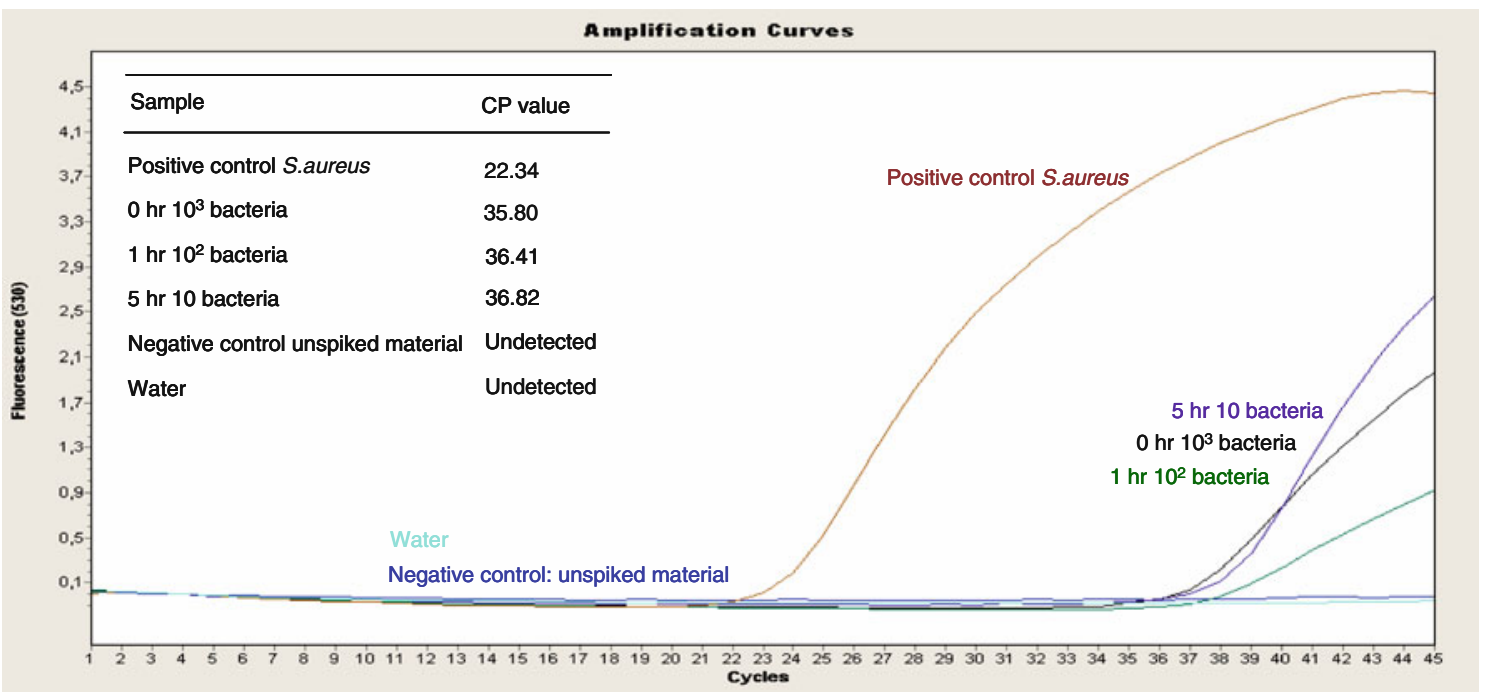

Fig. 1 Staphylococcus aureus detection in relation to reduced bacterial culture times. a Overview of the detection of $S$. aureus in relation to reduced culture times. BacT/ALERT blood culture bottles with the blood of healthy volunteers were spiked with $S$. aureus and samples were taken every hour. The experiments with 1,000 and 100 bacteria per bottle were performed once. The 1,000 bacteria/bottle experiment did not need a pre-culture step; a tuf real-time polymerase chain reaction (PCR) signal could be detected immediately after spiking $(0 \mathrm{~h})$. The 100 bacteria/bottle needed a pre-culture step of $1 \mathrm{~h}$

containing $100 \mathrm{CFU}$ of $S$. aureus $(10 \mathrm{CFU} / \mathrm{ml}$ blood $)$ resulted in positive real-time PCR signals after $1 \mathrm{~h}$ of incubation in the BacT/ALERT 3D. The 10-CFU bottles ( $1 \mathrm{CFU} / \mathrm{ml}$ blood) needed a maximum of $5 \mathrm{~h}$ of incubation in the BacT/ALERT 3D to be able to detect the $S$. aureus bacteria present using a subsequent PCR. The experiment with $10 \mathrm{CFU}$ of $S$. aureus per bottle was repeated eight times with both aerobe and anaerobe bottles and showed reproducible results. Standard deviations (SD) of the Cp values were calculated for the $10 \mathrm{CFU} /$ bottle experiments (aureus probe). The 3 -h time point ( $2 / 8$ positive) showed an SD of 3.44 , the 4-h time point (5/8 positive) indicated an SD of 1.09 and the 5-h time point ( $8 / 8$ positive) resulted in an SD of 1.09. Clinical strains of $S$. aureus and $S$. epidermidis were also spiked in BacT/ALERT blood culture bottles (aerobe [SA] and anaerobe [SN]) containing the blood of healthy volunteers. The results of these experiments were similar to in the BacT/ALERT 3D to obtain a positive signal in the real-time PCR. The experiment with 10 bacteria/bottle $(10 \mathrm{ml}$ blood $)$ was repeated eight times. Real-time PCR signal could be detected after a pre-culture step of $3-5 \mathrm{~h}$. All bottles, 8 of 8 , were positive after $5 \mathrm{~h}$ of pre-culture. Standard deviations (SD) for $10 \mathrm{CFU} /$ bottle were calculated as follows: $3 \mathrm{~h} \mathrm{SD} \mathrm{3.44,} 4 \mathrm{~h}$ SD 1.09 and $5 \mathrm{~h} \mathrm{SD} \mathrm{1.09.} \mathrm{b}$ LightCycler tuf real-time PCR result in the 530-nm fluorescence channel (S. aureus probe)

the results presented for the $S$. aureus ATCC 33592 strain. With conventional detection methods, the results of the bottles containing $10 \mathrm{CFU}$ of $S$. aureus were available after at least $28 \mathrm{~h}$.

\section{Discussion}

In this study, six different bacterial DNA extraction protocols were evaluated, by using a sensitive and specific tuf gene-based real-time PCR detection assay, which enabled the differentiation between $S$. aureus and CNS. From this study, it can be concluded that the MolYsis Plus kit (Molzym) in combination with the specific B protocol on the easyMAG (bioMérieux) resulted in the most optimal isolation of bacterial DNA from BacT/ALERT blood culture material. A detection limit of $10 \mathrm{CFU} / \mathrm{ml}$ was 
obtained in the tuf LightCycler assay for BacT/ALERT material. By using the tuf LightCycler assay, $1 \mathrm{CFU} / \mathrm{ml}$ of $S$. aureus or CNS could be detected from BacT/ALERT blood culture material when an incubation step of a maximum of $5 \mathrm{~h}$ was applied. By using this reduced incubation time, it was possible to identify $S$. aureus versus CNS within one working day.

Six different bacterial DNA extraction methods were compared on two commonly used blood culture systems (BACTEC and BacT/ALERT). The specific B protocol on the easyMAG contains the most washing steps compared to the generic and specific A protocol, possibly explaining the better results obtained with this isolation protocol. The bacterial DNA isolation performed with the MolYsis Plus kit resulted in a low detection limit for both culture systems. Gebert et al. published a study in 2008 in which they show that the MolYsis Plus kit performs well in their hands [25]. They used $500 \mu \mathrm{l}$ of input material and were able to conclude that PCR analysis in combination with MolYsis Plus DNA isolation resulted in accelerated detection of pathogens in blood culture samples. Inhibiting factors were not found to be present in the samples in the study of Gebert et al. [25]. In our study, no PCR inhibition was observed (all samples and controls showed similar $\mathrm{Cp}$ \pm 0.5 values in one run). The detection limit in the LightCycler assay, after MolYsis Plus isolation, was low, i.e. $10^{4} \mathrm{CFU} / \mathrm{ml}$. The MolYsis Plus kit eliminates human background DNA from the samples and enrichment of bacterial DNA takes place. Complete isolation with the MolYsis Plus kit takes $3 \mathrm{~h}$, of which $2 \mathrm{~h}$ is hands-on time. By using the easyMAG specific B protocol after completion of the MolYsis Plus Buglysis step, the total isolation time is not significantly reduced. However, the hands-on time and the chance for contamination are drastically reduced, due to the fact that column handling is skipped. A comparison between both culture systems resulted in a difference in bacterial DNA isolation efficiency. The use of BacT/ALERT blood culture material lead, in most isolation methods, to better results compared to BACTEC material. We experienced difficulties in the bacterial DNA isolations due to the beads present in BACTEC bottles, but we cannot conclude that the beads lead to the weaker performance of BACTEC material compared to BacT/ALERT material. However, due to this finding, all experiments were continued with the BacT/ALERT material.

By applying a 5-h incubation step for blood culture bottles containing approximately $10 \mathrm{CFU}$ of $S$. aureus or CNS, it was possible to detect these bacteria by the tuf LightCycler assay. These results could be produced within one working day when starting early in the morning. Compared to conventional culture techniques for staphylococci, the results were available at least $19 \mathrm{~h}$ faster. Gebert et al. [25] also showed in their paper that, by combining a sensitive real-time PCR and a sensitive isolation method, culture times can be reduced. They showed a 5.0-8.7$\mathrm{h}$ time gain in spiking experiments and an average time gain of $10.7 \mathrm{~h}$ was obtained when the method was applied on blood culture bottles of septic patients. The maximum time gain can be reached when starting either immediately in the morning or when the microbiology laboratory has a 24-h service. Laboratories with a 24-h setup will always benefit from this method.

The experiments described in this paper all focus on the accelerated detection of staphylococci, especially on the detection of $S$. aureus. Staphylococci were chosen as a model system because Gram-positive bacteria are frequently detected in blood culture bottles, making it a relevant group of micro-organisms for such a study [26-28]. Infections are, however, caused by a variety of pathogens. Staphylococci are fast-growing bacteria and, in this study, a proof-of-principle is shown. The accelerated detection of other pathogens causing bloodstream infections (i.e. Escherichia coli) directly from blood culture material in combination with reduced culture time and with this sensitive isolation method should be investigated in future experiments. It is of clinical importance in the future to focus especially on fastidious pathogens or fungi, since those pathogens are difficult to culture and, for these pathogens, the time to obtaining results can then, hopefully, be drastically reduced. A similar approach as presented in this study can be applied to investigate reduced incubation times for other pathogens.

It is known from the literature that staphylococci are the most frequent causative agent of medical-device-related and surgical-site infections [7]. Therefore, it is interesting to apply the tuf LightCycler duplex assay in these patient groups using whole blood samples. The preliminary results showed that the MolYsis Complete kit (Molzym) has already proven to be successful in our hands (data not shown), as well as in the hands of others [29].

In conclusion, by combining the MolYsis Plus kit and the specific B protocol on the easyMAG, $10 \mathrm{CFU} / \mathrm{ml}$ could be detected from $S$. aureus-spiked BacT/ALERT blood culture material. By applying this isolation method followed by the sensitive tuf LightCycler duplex assay, using 5-h-incubated spiked blood culture material, 1 CFU of $S$. aureus or CNS per $1 \mathrm{ml}$ of blood could be detected. Future studies are needed in order to address the clinical application of this approach.

Acknowledgements We thank Wendy Hansen, Jitske Stalpers, Marielle Bierma, Christel van Herk, Paul van Kaathoven, Gitta Stienen and Jan Michielse for their technical support.

Conflict of interest The authors declare that they have no conflict of interest. 
Open Access This article is distributed under the terms of the Creative Commons Attribution Noncommercial License which permits any noncommercial use, distribution, and reproduction in any medium, provided the original author(s) and source are credited.

\section{References}

1. Lowy FD (1998) Staphylococcus aureus infections. N Engl J Med 339:520-532

2. Centers for Disease Control and Prevention (CDC) (1992) Report of mortality statistics. Mon Vital Stat Rep 40:1-23

3. van Gestel A, Bakker J, Veraart CP, van Hout BA (2004) Prevalence and incidence of severe sepsis in Dutch intensive care units. Crit Care 8:R153-R162

4. Saginur R, Suh KN (2008) Staphylococcus aureus bacteraemia of unknown primary source: where do we stand? Int J Antimicrob Agents 32(Suppl 1):S21-S25

5. von Eiff C, Peters G, Heilmann C (2002) Pathogenesis of infections due to coagulase-negative staphylococci. Lancet Infect Dis 2:677-685

6. Piette A, Verschraegen G (2009) Role of coagulase-negative staphylococci in human disease. Vet Microbiol 134:45-54

7. Huebner J, Goldmann DA (1999) Coagulase-negative staphylococci: role as pathogens. Annu Rev Med 50:223-236

8. Kloos WE, Bannerman TL (1994) Update on clinical significance of coagulase-negative staphylococci. Clin Microbiol Rev 7:117-140

9. Wellinghausen N, Wirths B, Franz AR, Karolyi L, Marre R, Reischl U (2004) Algorithm for the identification of bacterial pathogens in positive blood cultures by real-time LightCycler polymerase chain reaction (PCR) with sequence-specific probes. Diagn Microbiol Infect Dis 48:229-241

10. Sakai H, Procop GW, Kobayashi N, Togawa D, Wilson DA, Borden L, Krebs V, Bauer TW (2004) Simultaneous detection of Staphylococcus aureus and coagulase-negative staphylococci in positive blood cultures by real-time PCR with two fluorescence resonance energy transfer probe sets. J Clin Microbiol 42:5739-5744

11. Granger K, Rundell MS, Pingle MR, Shatsky R, Larone DH, Golightly LM, Barany F, Spitzer ED (2009) Multiplex PCR-ligation detection reaction assay for simultaneous detection of drug resistance and toxin genes from Staphylococcus aureus, Enterococcus faecalis, and Enterococcus faecium. J Clin Microbiol 48:277-280

12. Hartmann H, Stender H, Schäfer A, Autenrieth IB, Kempf VA (2005) Rapid identification of Staphylococcus aureus in blood cultures by a combination of fluorescence in situ hybridization using peptide nucleic acid probes and flow cytometry. J Clin Microbiol 43:4855-4857

13. Peters RP, van Agtmael MA, Simoons-Smit AM, Danner SA, Vandenbroucke-Grauls CM, Savelkoul PH (2006) Rapid identification of pathogens in blood cultures with a modified fluorescence in situ hybridization assay. J Clin Microbiol 44:4186-4188

14. Stevenson LG, Drake SK, Murray PR (2010) Rapid identification of bacteria in positive blood culture broths by matrix-assisted laser desorption ionization-time of flight mass spectrometry. J Clin Microbiol 48:444-447
15. Yoo SM, Choi JY, Yun JK, Choi JK, Shin SY, Lee K, Kim JM, Lee SY (2010) DNA microarray-based identification of bacterial and fungal pathogens in bloodstream infections. Mol Cell Probes 24:44-52

16. Cleven BE, Palka-Santini M, Gielen J, Meembor S, Krönke M, Krut O (2006) Identification and characterization of bacterial pathogens causing bloodstream infections by DNA microarray. J Clin Microbiol 44:2389-2397

17. Avolio M, Diamante P, Zamparo S, Modolo ML, Grosso S, Zigante P, Tosoni N, De Rosa R, Stano P, Camporese A (2010) Molecular identification of bloodstream pathogens in patients presenting to the emergency department with suspected sepsis. Shock 34:27-30

18. Dierkes C, Ehrenstein B, Siebig S, Linde HJ, Reischl U, Salzberger B (2009) Clinical impact of a commercially available multiplex PCR system for rapid detection of pathogens in patients with presumed sepsis. BMC Infect Dis 9:126

19. Wallet F, Nseir S, Baumann L, Herwegh S, Sendid B, Boulo M, Roussel-Delvallez M, Durocher AV, Courcol RJ (2010) Preliminary clinical study using a multiplex real-time PCR test for the detection of bacterial and fungal DNA directly in blood. Clin Microbiol Infect 16:774-779

20. Wilson IG (1997) Inhibition and facilitation of nucleic acid amplification. Appl Environ Microbiol 63:3741-3751

21. Al-Soud WA, Rådström $P$ (2001) Purification and characterization of PCR-inhibitory components in blood cells. J Clin Microbiol 39:485-493

22. Millar BC, Jiru X, Moore JE, Earle JA (2000) A simple and sensitive method to extract bacterial, yeast and fungal DNA from blood culture material. J Microbiol Methods 42:139-147

23. Fredricks DN, Relman DA (1998) Improved amplification of microbial DNA from blood cultures by removal of the PCR inhibitor sodium polyanetholesulfonate. J Clin Microbiol $36: 2810-2816$

24. van Doornum GJ, Guldemeester J, Osterhaus AD, Niesters HG (2003) Diagnosing herpesvirus infections by real-time amplification and rapid culture. J Clin Microbiol 41:576-580

25. Gebert S, Siegel D, Wellinghausen N (2008) Rapid detection of pathogens in blood culture bottles by real-time PCR in conjunction with the pre-analytic tool MolYsis. J Infect 57:307-316

26. Alberti C, Brun-Buisson C, Burchardi H, Martin C, Goodman S, Artigas A, Sicignano A, Palazzo M, Moreno R, Boulmé R, Lepage E, Le Gall R (2002) Epidemiology of sepsis and infection in ICU patients from an international multicentre cohort study. Intensive Care Med 28:108-121

27. Annane D, Bellissant E, Cavaillon JM (2005) Septic shock. Lancet 365:63-78

28. Martin GS, Mannino DM, Eaton S, Moss M (2003) The epidemiology of sepsis in the United States from 1979 through 2000. N Engl J Med 348:1546-1554

29. Hansen WL, Bruggeman CA, Wolffs PF (2009) Evaluation of new preanalysis sample treatment tools and DNA isolation protocols to improve bacterial pathogen detection in whole blood. J Clin Microbiol 47:2629-2631 